\title{
DESAIN PENGEMBANGAN ENSIKLOPEDIA TANAMAN OBAT BERBASIS POTENSI LOKAL DI PULAU LOMBOK
}

\author{
Widya Fitri Hana ${ }^{1}$, Maya Ekaningtias ${ }^{2}$, Siti Wardatul Jannah ${ }^{3}$ \\ 1,2,3 Program Studi Pendidikan Biologi FKIP UNW Mataram \\ Email: mentias4life@gmail.com
}

\begin{abstract}
Abstrak
Penelitian ini bertujuan untuk mengembangkan desain produk pengembangan ensiklopedia tanaman obat berdasarkan hasil penelitian tentang tumbuhan obat yang telah dilakukan di Pulau Lombok. Jenis penelitian yang digunakan adalah Research and Development (R\&D). Model pengembangan yang digunakan dalam penelitian ini adalah model 4-D dari Thiagarajan, Semmel dan Sammel yang meliputi 3 tahapan yaitu pendefinisian (Define), perancangan (Design), dan pengembangan (Develop). Hasil penelitian ini berupa draft ensiklopedia tanaman obat berbasis potensi lokal di Pulau Lombok.
\end{abstract}

Kata Kunci : Ensiklopedia, Tanaman Obat, Potensi Lokal

\section{PENDAHULUAN}

Hutan tropik Indonesia diperkirakan mencapai 143 juta ha, tempat tumbuh $80 \%$ dari tanaman obat yang ada di dunia yakni sebanyak 28.000 spesies tanaman tumbuhan dan 1.000 spesies diantaranya telah digunakan sebagai tanaman obat (Fahrurozi, 2014 dalam Qamariah dkk, 2018). Tumbuhan obat adalah tumbuhan yang salah satu atau seluruh bagian pada tumbuhan tersebut mengandung zat aktif yang berkhasiat bagi kesehatan yang dapat dimanfaatkan sebagai penyembuh penyakit. Masyarakat memanfaatkan tumbuhan obat yang ada sebagai bahan baku obat-obatan berdasarkan pengetahuan tentang pemanfaatan tumbuhan obat yang diwariskan secara turuntemurun (Hidayat dan Hardiansyah, 2013).
Suku Sasak yang merupakan masyarakat asli daerah ini masih mengandalkan beberapa tanaman yang digunakan sebagai obat tradisional. Pengetahuan masyarakat Sasak tentang obat-obatan diperoleh dari naskah daun Lontar Usada Lombok yang sudah berusia ratusan tahun, dan merupakan warisan turun temurun. Kearifan lokal ini bermula dari hasil uji coba masyarakat (trial and error) terhadap tumbuh-tumbuhan yang ada di sekitar tempat hidup mereka untuk memenuhi kebutuhan akan pengobatan. Kearifan lokal masyarakat tersebut akhirnya terkristalisasi menjadi suatu pegangan bagi mereka dalam memenuhi kebutuhan akan pengobatan (Jannah dan Ridwan, 2013). 
Penduduk Lombok banyak menggunakan obat tradisional/tumbuhan obat karena selain biayanya yang relatif murah, juga karena mudah diperoleh berkat potensi alam yang kaya dan juga merupakan warisan turun temurun. Namun, tidak semua kearifan lokal yang terdapat dalam budaya lokal masyarakat Lombok tersebut telah diketahui oleh masyarakat. Terlebih lagi muncul permasalahan serius yang perlu untuk segera disikapi yaitu terkikisnya kebiasaan masyarakat setempat dalam hal pengobatan secara tradisional akibat kemajuan ilmu kedokteran yang sangat pesat sehingga masyarakat menjadi tergantung dengan obatobatan kimiawi dan mulai lupa dengan potensi lokal yang dimilikinya (terkikisnya kearifan lokal masyarakat dalam hal pengobatan tradisional). Hal ini menyebabkan kurangnya perhatian masyarakat terhadap pembudidayaan tanaman-tanaman obat tersebut sehingga tanaman-tanaman tersebut mulai sulit didapatkan. Selain itu, konversi hutan menjadi non hutan juga ikut menyebabkan terkikisnya kebiasaan masyarakat Lombok tersebut (Jannah dan Ridwan, 2013).

Oleh karena itu, salah satu usaha konservasi untuk mendukung kelestarian tanaman obat di pulau Lombok adalah memperkenalkan kepada masyarakat luas tentang manfaat tanaman yang berpotensi obat di pulau Lombok melalui pengembangan ensiklopedia yang berisi jenis tanaman yang berkhasiat obat. Tujuan penelitian ini adalah untuk menghasilkan desain produk pengembangan ensiklopedia tanaman obat berbasis potensi lokal dan mengetahui kelayakan ensiklopedia tanaman obat berbasis potensi lokal yang telah dikembangkan berdasarkan penilaian pakar.

\section{METODE}

Jenis penelitian yang digunakan adalah Research and Development (R\&D). Model pengembangan yang digunakan dalam penelitian ini adalah model 4-D dari Thiagarajan, Semmel dan Sammel. Model pengembangan ini terdiri dari 4 tahapan yaitu pendefinisian (Define), perancangan (Design), pengembangan (Develop), dan penyebarluasan (disseminate) (Setiawan, 2017). Namun untuk penelitian ini hanya dilakukan sampai tahapan develop saja. Adapun populasi dalam penelitian ini adalah semua jenis tumbuhan yang berpotensi sebagai obat yang telah ditemukan di Pulau Lombok. Sampel dalam penelitian ini adalah seratus (100) jenis tumbuhan yang berpotensi sebagai obat yang telah ditemukan di Pulau Lombok. Instrumen yang digunakan adalah lembar validasi penilaian para validator (ahli materi dan ahli media) terhadap produk ensiklopedia tanaman obat yang dikembangkan. Teknik pengumpulan data meliputi: studi literatur 
tanaman berpotensi obat di Pulau Lombok, wawancara, dokumentasi, penyebaran angket kepada ahli media dan ahli materi untuk menilai kelayakan produk ensiklopedia, dan revisi desain ensiklopedia berdasarkan penilaian para ahli. Analisis uji kelayakan ensiklopedia menggunakan rumus statistik sebagai berikut:

$$
\text { presentase }=\frac{A}{B} \times 100 \%
$$

Keterangan:

$\mathrm{A}=$ banyaknya skor yang diperoleh

$\mathrm{B}=$ skor maksimal

(Trianto, 2010 dalam Assani, 2017)

Pengelompokkan kategori validasi disajikan pada Tabel 1 berikut:

Tabel 1. Persentase Tingkat Validasi Ensiklopedia Tanaman Obat

\begin{tabular}{|c|l|}
\hline $\begin{array}{c}\text { Pencapaian } \\
\text { nilai (skor) }\end{array}$ & \multicolumn{1}{|c|}{ Tingkat Validasi } \\
\hline $81-100 \%$ & $\begin{array}{l}\text { Sangat valid, atau dapat } \\
\text { digunakan tanpa revisi }\end{array}$ \\
\hline $61-80 \%$ & $\begin{array}{l}\text { Valid, atau dapat digunakan } \\
\text { namun perlu direvisi kecil }\end{array}$ \\
\hline $41-60 \%$ & $\begin{array}{l}\text { Kurang valid, disarankan tidak } \\
\text { dipergunakan karena perlu } \\
\text { direvisi besar }\end{array}$ \\
\hline $21-40 \%$ & $\begin{array}{l}\text { Tidak valid atau tidak boleh } \\
\text { dipergunakan }\end{array}$ \\
\hline $0-20 \%$ & $\begin{array}{l}\text { Sangat tidak valid, tidak boleh } \\
\text { dipergunakan }\end{array}$ \\
\hline
\end{tabular}

(Akbar, 2013 dalam Assani, 2017)

\section{HASIL DAN PEMBAHASAN}

Berdasarkan studi pustaka atau studi literatur tentang tanaman berpotensi obat di pulau Lombok dan hasil wawancara dengan Belian Sasak bahwa terdapat 100 spesies tanaman yang terdiri dari 52 Famili yaitu 4 Apiaceae, 1 Poaceaae, 1 Lauraceae, 6 Fabaceae, 1 Moraceae, 7 Asteraceae, 1 Amaryllidaceae, $\quad 1 \quad$ Alliaceae, 1 Amaranthaceae, 1 Oxalidaceae, 1 Geraniales, 3 Malvaceae, 1 Basellaceae, 4 Rubiaceae, 1 Nyctaginaceae, 2 Piperaceae, 4 Solanaceae, 5 Myrtaceae, 5 Euphorbiaceae, 1 Crasulaceae, 2 Araceae, 1 Menispermaceae, 1 Lumiaceae, 4 Rutaceae, 2 Meliaceae, 3 Apocynaceae, 1 Punicaceae, 1 Butamaceae, 6 Zingiberaceae, 2 Cucurbetaceae, 1 Portulacaceae, 1 Agavaceae, 1 Acoraceae, 1 Moringaceae, 1 Arecaceae, 1 Lamiaceae, 3 Annonaceae, 1 Labiatae, 1 Asphodelaceae, 1 Cruciferae, 1 Clusiaceae, 2 Poaceae, 1 Pandanaceae, 1 Cucurbitaceae, 2 Verbenaceae, 1 Caricaceae, 1 Palmae, 1 Musaceae, 1 Mimosaceae, 1 Sapindaceae, 1 Caesalpiniaceae dan 1 Convolvulaceae. Berdasarkan hasil wawancara dengan salah satu Belian Sasak bahwa tanaman obat yang umum digunakan adalah jarak, kencur, kunyit, cabai jawa, jahe, ketumbar, asam, sirih dan jeruk nipis.

Ahli media memvalidasi desain ensiklopedia, sedangkan ahli materi memvalidasi materi ensiklopedia. Adapun hasil validasi oleh ahli materi dapat dilihat pada Tabel 2 berikut: 
Tabel 2. Hasil Validasi Ensiklopedia Ahli Materi

\begin{tabular}{|c|l|c|}
\hline $\begin{array}{c}\mathrm{N} \\
\mathrm{o}\end{array}$ & \multicolumn{1}{|c|}{ Aspek Evaluasi } & $\begin{array}{c}\text { Skor } \\
\text { Validasi }\end{array}$ \\
\hline 1. & Keakuratan Materi & 17 \\
\hline 2. & Kemutakhiran Materi & 6 \\
\hline 3. & Mendorong Keingintahuan & 3 \\
\hline 4. & Teknik Penyajian & 2 \\
\hline 5. & Pendukung Penyajian & 10 \\
\hline 6. & Hakikat Kontekstual & 7 \\
\hline 7 & Komponen Kontekstual & 8 \\
\hline Jumlah Skor & 53 \\
\hline Persentase & $77,94 \%$ \\
\hline
\end{tabular}

Berdasarkan Tabel 2, hasil validasi ahli materi sebesar $77,94 \%$ artinya materi Ensiklopedia Tanaman Obat termasuk kategori valid namun dapat digunakan setelah direvisi. Tanaman Obat di Pulau Lombok yang sudah teridentifikasi dimuat sebagai materi dalam Ensiklopedia Tanaman Obat. Setiap spesies dalam satu halaman memuat gambar spesies, klasifikasi, deskripsi, habitus, habitat, manfaat dan cara pengolahan tanaman obat sesuai jenis penyakit.

Hasil validasi oleh ahli media dapat dilihat pada Tabel 3.

Tabel 3. Hasil Validasi Ensiklopedia Ahli Media

\begin{tabular}{|l|l|c|}
\hline No. & \multicolumn{1}{|c|}{ Aspek Evaluasi } & $\begin{array}{c}\text { Skor } \\
\text { Validasi }\end{array}$ \\
\hline 1. & Ukuran Ensiklopedia & 8 \\
\hline 2. & $\begin{array}{l}\text { Desain Sampul } \\
\text { Ensiklopedia }\end{array}$ & 25 \\
\hline 3. & Desain Isi Ensiklopedia & 65 \\
\hline Jumlah Skor & 98 \\
\hline \multicolumn{2}{|l|}{ Persentase } & $90,7 \%$ \\
\hline
\end{tabular}

Uji kelayakan oleh ahli media bertujuan untuk mengetahui kualitas penyajian media Ensiklopedia Tanaman Obat. Hasil validasi oleh ahli media yaitu 90,7\%. Hal ini menunjukkan bahwa Ensiklopedia Tanaman Obat berada pada kategori sangat valid atau dapat digunakan tanpa revisi.

Ensiklopedia memuat informasi penting yang dilengkapi dengan gambar atau foto pendukung, penataan ensiklopedia juga berdasarkan abjad atau pengelompokan tertentu sehingga ensiklopedia mudah digunakan. Materi Ensiklopedia Tanaman Obat merupakan hasil meneliti dan memahami buku-buku, dokumen, jurnal, artikel atau sumber tertulis lainnya yang relevan terkait dengan tumbuhan obat yang ada di Pulau Lombok. Spesies atau jenis tanaman obat disusun berdasarkan urutan abjad nama lokal tanaman.

Ensiklopedia Tanaman Obat dilengkapi dengan petunjuk penggunaan buku dan glosarium. Format ensiklopedia secara lengkap yaitu: sampul, kata pengantar, daftar isi, petunjuk penggunaan buku, jenis-jenis tanaman berpotensi obat, glosarium dan daftar pustaka. 

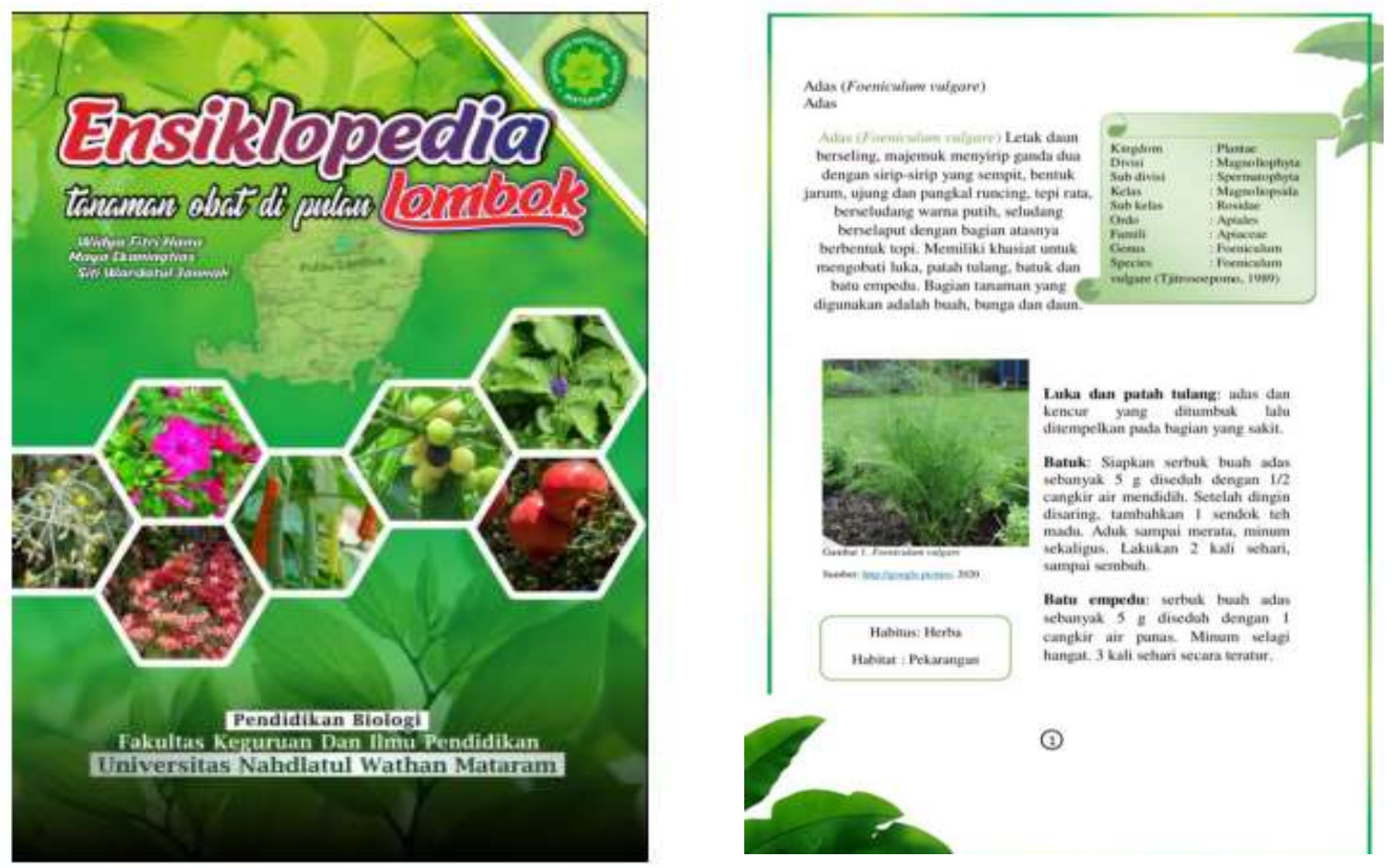

Gambar 1. Sampul dan Cuplikan Isi Ensiklopedia Tanaman Obat
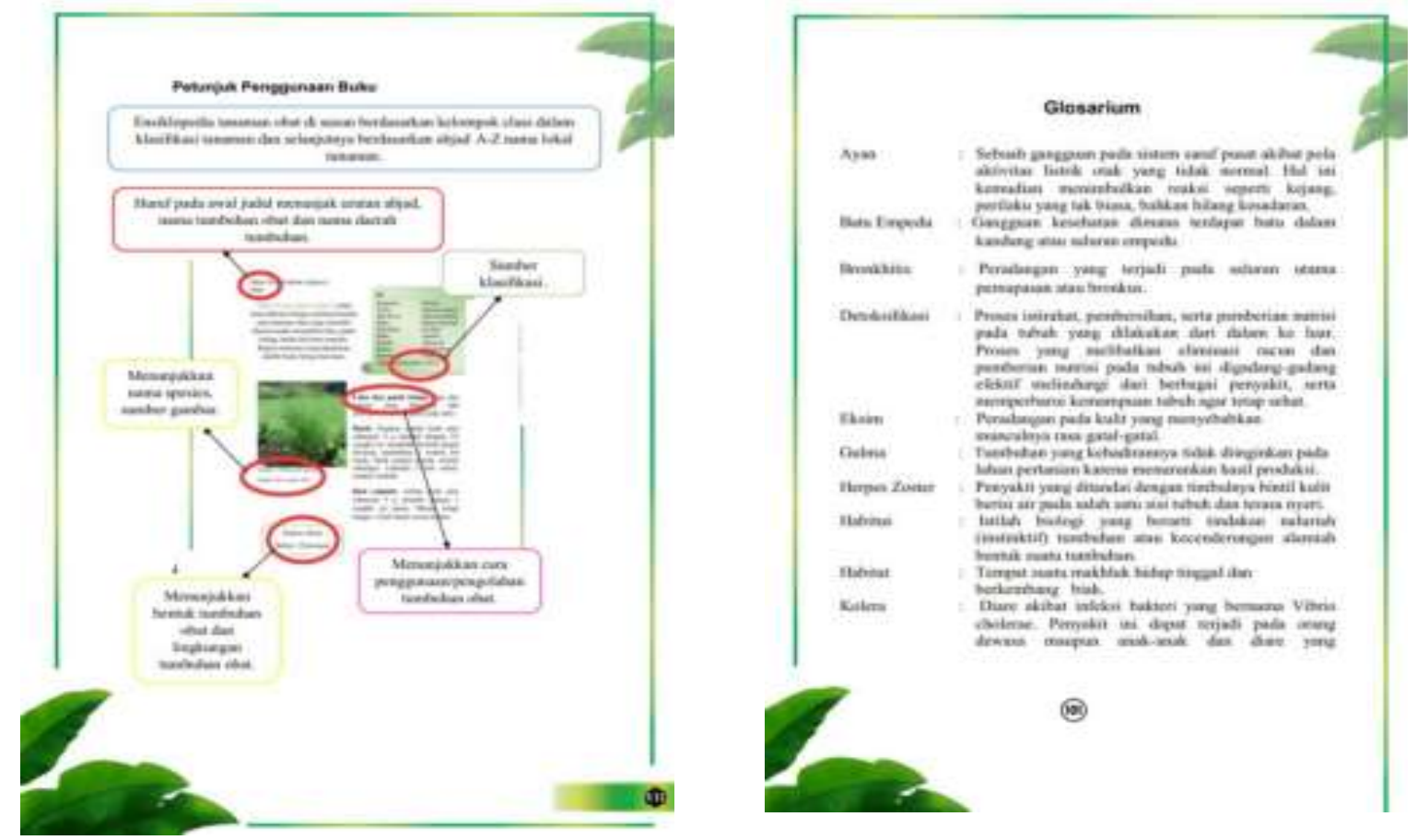

Gambar 2. Petunjuk Penggunaan Ensiklopedia Tanaman Obat dan Glossarium 


\section{KESIMPULAN}

Dari penelitian ini dapat disimpulkan bahwa terdapat 100 jenis tanaman obat yang tekah diketahui oleh masyarakat dan tercantum dalam materi Ensiklopedia Tanaman Obat. Nilai uji validasi dari ahli materi sebesar $77 \%$ sedangkan nilai uji validasi ahli media sebesar 90\%. Dari hasil validasi ahli materi dan ahli media menunjukkan bahwa ensiklopedia tanaman obat berbasis potensi lokal di Pulau Lombok layak digunakan.

\section{DAFTAR PUSTAKA}

Assani, F. Z. R. (2017). Pengembangan Ensiklopedia Spermatophyta Berbasis Potensi Lokal Di Makam Sunan Kalijaga Dan Masjid Agung Demak Sebagai Sumber Belajar Materi Plantae Kelas X SMA/MA. Disertasi, Universitas Islam Negeri Walisongo Semarang.

Hidayat, D., dan Hardiansyah, G. (2013). Studi Keanekaragaman Jenis Tumbuhan Obat Di Kawasan IUPHHK PT. Sari Bumi Kusuma Camp Tontang Kabupaten Sintang. Jurnal Vokasi, 8 (2), 61-68.

Jannah, H., \& Ridwan, R. (2013). Pengobatan Tradisional Suku Sasak Berbasis Ilmiah Di Kabupaten Lombok Barat. Bioscientist: Jurnal Ilmiah Biologi, 1(2), 116-125.

Setiawan, D.C. (2018). Pemanfaatan Pengembangan Petunjuk Praktikum Materi Regenerasi Dan Pigmentasi Terhadap Motivasi Mahasiswa Program Studi Biologi IKIP Budi Utomo Malang. Seminar Nasional Pendidikan IPA 2017, Vol 2, 427-431
Qamariah, N., Mulyani, E., \& Dewi, N. (2018). Inventarisasi Tumbuhan Obat di Desa Pelangsian Kecamatan Mentawa Baru Ketapang Kabupaten Kotawaringin Timur. Borneo Journal of Pharmacy, 1(1), 1-10. 